\title{
The Antihyperglycaemic Effect of the Methanol Stem-Bark Extract of Ficus capensis Thunb (Moraceae) and its Fractions on Alloxan- Induced Hyperglycaemia in Wistar Rats
}

\author{
Sani, Mohammed Bashir ${ }^{1 *}$, Olorukooba, Amina Busola ${ }^{1}$, Aliyu, Muazzamu Ibrahim ${ }^{1}$, Ya'u, \\ Jamilu $^{1}$, Muhammad Sani, Salihu ${ }^{2}$ \\ ${ }^{I}$ Department of Pharmacology and Therapeutics, Faculty of Pharmaceutical Sciences, Ahmadu Bello University, \\ Zaria-Nigeria \\ ${ }^{2}$ Department of Pharmaceutical Microbiology and Biotechnology, Faculty of Pharmaceutical Science, Kaduna \\ State University, Kaduna-Nigeria
}

*Corresponding Author: Mohammed Bashir, Department of Pharmacology and Therapeutics, Faculty of Pharmaceutical Sciences, Ahmadu Bello University, Zaria-Nigeria

\begin{abstract}
:
Background: The plant Ficus capensis is found in Sub-Saharan Africa, South Africa and South America. It is used for threatened abortion, rheumatism, fever, epilepsy, and traditional cure of diabetes mellitus in southwestern Nigeria.
\end{abstract}

Objective: This study was aimed at evaluating the antihyperglycaemic effect of the methanol stem-bark extract of Ficus capensis (Thunb) and it fractions on alloxan induced hyperglycaemia in Wistar rats.

Method: Methanol stem bark extract of Ficus capensis (MSFCE) and its Fractions (Ethyl Acetate Fraction $(E A F)$, n-Butanol Fraction (NBF), and Residual Aqueous Fraction (RBF)\} were subjected to preliminary phytochemical screening, Oral median lethal dose $\left(L D_{50}\right)$ determination. The antihyperglycaemic activity of the extract and its fractions at doses of 100, 200, and $400 \mathrm{mg} / \mathrm{kg}$ body weight orally on Alloxan-Induced Hyperglycaemia in Wistar rats was investigated and were carried out. Thirty six (36) were divided into six (6) groups of six (6) rats each, the $1^{\text {st }}$ group (normal rats) served as the negative control received distilled water $1 \mathrm{ml} / \mathrm{kg}$, the $2^{\text {nd }}$ group (hyperglycaemic control) while the $3^{\text {rd }}, 4^{\text {th }}, 5^{\text {th }}$ (hyperglycaemic rats) received MSFCE and its fractions at doses of $\left(100,200\right.$ and $400 \mathrm{mg} / \mathrm{kg}$ respectively) and the $6^{\text {th }}$ group of hyperglycaemic rats received Metformin $100 \mathrm{mg} / \mathrm{kg}$ served as positive control. The treatments were given orally and once a day.

Results: Preliminary phytochemical constituents of the extract and its fractions revealed the presence of alkaloids, cardiac glycosides, flavonoids, saponins, tannins, steroids, phenols and triterpenes. $L D_{50}$ of the extract and its fractions in Wistar rats were found to be greater than 5,000 $\mathrm{mg} / \mathrm{kg} \mathrm{bw} \mathrm{p.o.} \mathrm{The} \mathrm{extract} \mathrm{at} \mathrm{its}$ fractions at tested doses $(100,200$ and $400 \mathrm{mg} / \mathrm{kg} \mathrm{bw})$ significantly $(p<0.05,0.01$ and 0.001$)$ decreased blood glucose level after 2, 4, 8, 16 and $24 \mathrm{hr}$ post administration when compared with diabetic control). On comparison over time from zero $\mathrm{hr}$, the extract and its fractions at doses tested exhibited significant $(p<0.05$, 0.01 and 0.001 ) decreased blood glucose levels after the $2^{\text {nd }}, 4^{\text {th }}, 8^{\text {th }}$ and $16^{\text {th }}$ hr after administration.

Conclusion: These findings suggest that the extract and its Fractions possess antihyperglycaemic property which supports the ethno medical use of the plant in the management of diabetes mellitus.

Keywords: Phytochemical constituents, Oral median lethal dose $\left(L D_{50}\right)$ and blood glucose

\section{INTRODUCTION}

The term diabetes mellitus describes a metabolic disorder of multiple etiologies characterized by chronic hyperglycaemia with disturbances of carbohydrate, fat and protein metabolism resulting from defects in insulin secretion, insulin action or both (American Diabetes Association, 2013). The effect of diabetes 
mellitus includes long-term damage, dysfunction and failure of various organs (Fowler, 2008). The International Diabetes Federation (International Diabetes Federation, 2015) estimated that about 415 million adults, aged 20 to 79 years have diabetes worldwide, or about one in every 11, with type 2 which represents approximately $90 \%$ of the cases worldwide and this is expected to increase to 642 million by the year 2040 (Wild et al., 2004 and International Diabetes Federation, 2015)

Regardless of the type of diabetes, patients are required to control their blood glucose levels with medications such as insulin and oral antidiabetic agents that include sulphonylureas, biguanides, alpha glucosidase inhibitors, thiozolidinedione derivatives, newer oral antidiabetic agents such as Aldose reductase inhibitors, Amylin agonist, Glucagon like peptide-1 and or by adhering to an exercise programme and a dietary plan (Wolf et al., 2004). The problems posed by agents used in management of diabetes mellitus include: expensiveness, adverse effects such as severe hypoglycemia, lactic acidosis, and peripheral edema, abdominal discomfort and require long duration of therapy (Sulaiman et al., 2006 and Lorenzati et al., 2010). Thus searching for a new class of compound from medicinal plants is essential to overcome side effects (Sulaiman et al., 2006).

Alloxan-induced hyperglycaemia is a useful model to study the activity of hypoglycaemic agents (Szukudelski et al., 2001). Alloxan is well known for its selective pancreatic islet $\beta$ cell cytotoxity and has been used to induce diabetes in animals. The underlying mechanism of alloxan is still unclear. However, it probably exerts its diabetogenic effect by the production of hydrogen peroxide in intact tissues via generation of reactive oxygen species (Drews et al., 2000). It interferes with cellular metabolic oxidative mechanisms forming highly reactive superoxide radicals which destroy the insulin producing cells in the pancreas. The selective uptake of this cytotoxic agent might account for its well known diabetogenic effect (Gorus et al., 1982).

Ficus capensis Thunb belongs to the family Moraceae. Ficus capensis is found in Sub-Saharan Africa, South Africa and South America mostly along rivers. It is commonly known as fig tree spreading deciduous or evergreen tree with thick bole and spreading roots. It produces fruits throughout the year and the leaves are broad and green. In Nigeria $F$. capensis has been used by Igede people as treatment for dysentery and wound dressing (Igoli et al., 2005). It is also used for the traditional cure of diabetes mellitus in south-western Nigeria (Soladoye et al., 2012).

There is paucity of scientific information regarding the effect of Ficus capensis on blood glucose levels, hence the present study was carried out to investigate the antihyperglycaemic effect of the methanol stembark extract of Ficus capensis (Thunb) and its Fraction on alloxan induced hyperglycaemia in Wistar rats.

\section{MATERIALS AND METHOD}

\subsection{Animals}

Wistar rats (160 - $200 \mathrm{~g})$ of either sex were purchased from and maintained in Animal House, Department of Pharmacology and Therapeutics Faculty of Pharmaceutical Sciences Ahmadu Bello University, Zaria. They were housed in a well ventilated room, fed with standard Vital Feed@ and water ad libitum

\subsection{Plant material}

The stem-bark of Ficus capensis was collected in March, 2013 at Basawa village, Samaru Zaria. It was identified and authenticated by Botanist Mal. Umar Shehu Gallah of the herbarium section, Department of Botany, Ahmadu Bello University, Zaria by comparing with voucher specimen number 901459 deposited in the herbarium for future reference.

\subsection{Plant extraction}

\subsubsection{Preparation of the Plant Extract}

The method described by (Handa et al., 2008) was employed. The stem bark of the plant was washed and cut into small pieces and air dried under shade. The dried plant material was chopped and finely grounded using pestle and mortar. About $500 \mathrm{~g}$ dried and powdered stem-bark of Ficus capensis was macerated 
with $2 \mathrm{~L}$ of aqueous methanol solution $(70 \% \mathrm{v} / \mathrm{v}$ methanol and $30 \% \mathrm{v} / \mathrm{v}$ water) at room temperature for a period of seven (7) days with intermittent agitation. The extract was filtered with the aid of Whatman No. 3 filter paper. The filtrate was concentrated to dryness at room temperature where a dark brown residue referred to as crude methanol stem bark extract was obtained. The crude methanol stem-bark extract obtained was kept in a dessicator until needed for use.

\section{3. 2 Fractionation of crude methanol stem bark extract of Ficus capensis (MSFCE)}

The method described by (Handa et al., 2008) was employed. $50 \mathrm{~g}$ of the crude MSFCE was dissolved in $600 \mathrm{ml}$ distilled water and filtered. The filtrate was successively partitioned three times each with nhexane, chloroform, ethyl acetate and n-butanol in order of polarity resulting to various fractions. The fractions were kept separately in a dessicator until required for use. Solutions of the fractions were freshly prepared with distilled water for each day of the experiment.

\section{4. Phytochemical screening}

Phytochemical Screening of the crude methanol stem bark extract of Ficus capensis and its fractions were conducted according to the methods described by (Evans et al., 2002)

\section{5. Preparation of extract and treatment}

Different stock solutions of MSFCE and its fractions: ethyl acetate fraction (EAF), n-butanol fraction (NBF) and residual aqueous fraction (RAF) were prepared using distilled water followed by serial dilution to obtain the final experimental concentrations. The solutions were freshly prepared daily and orally administered with the aid of oral gavages.

\section{6. Acute toxicity study}

The method described by (Lorke, 1983) for determining the median lethal dose was used. It was carried out in two phases. In the initial phase, three (3) groups of three (3) rats each were administered with the ethyl acetate fraction of methanol stem bark extract of Ficus capensis (EAF) at doses of 10, 100 and 1000 $\mathrm{mg} / \mathrm{kg}$ body weight orally ( $b w$ p.o). The rats were observed in the first four (4) hours and 24 hours for signs and symptoms of toxicity such as sniffing, restlessness, hyperactivity, leaking of paws, defaecation, stretching, and protrusion of the eye balls, calmness and death. In the second phase, three (3) fresh rats were divided into three (3) groups of one (1) rat each and administered with EAF at doses of 1600, 2900, and $5000 \mathrm{mg} / \mathrm{kg} \mathrm{bw} \mathrm{p.o} \mathrm{respectively,} \mathrm{based} \mathrm{on} \mathrm{result} \mathrm{obtained} \mathrm{in} \mathrm{the} \mathrm{first} \mathrm{phase.} \mathrm{The} \mathrm{rats} \mathrm{were} \mathrm{observed}$ for signs and symptoms of toxicity and death over a period of 24 hour. The $\mathrm{LD}_{50}$ value was calculated as geometric mean of the highest non lethal dose which the animals survived and lowest lethal dose that caused death.

\section{$\mathrm{LD}_{50}=\sqrt{\text { highest }}$ nonlethal dose $\times$ lowest lethal dose}

\subsection{Effect of Methanol Stem Bark Extract of Ficus capensis and its fraction on Alloxan induced hyperglycaemia in Wistar rats}

The method described by (Dhandapani et al., 2002) was employed in 12 hours overnight fasted normal rats. The rats were injected with alloxan monohydrate dissolved in sterile $0.9 \%$ normal saline at a dose of $150 \mathrm{mg} / \mathrm{kg}$ intraperitoneally (i.p). The rats were kept for the next $24 \mathrm{~h}$ on $10 \%$ glucose solution in their cages to prevent hypoglycaemia. Seventy two (72) hours post administration of alloxan; rats were examined for hyperglycaemia at intervals of $0,2,4,8$, and 24 hours and estimated using a glucose oxidase - peroxidase reactive strips and a glucometer. Rats with blood glucose of $180 \mathrm{mg} / \mathrm{dL}$ and above were selected and used in the study. The alloxan induced hyperglycemic Wistar rats were randomly divided into five (5) groups of six (6) rats each as follows:

Group I: $\quad$ Normal rats received distilled water $1 \mathrm{ml} / \mathrm{kg}$

Group II: $\quad$ Hyperglycaemic control received distilled water at dose of $1 \mathrm{ml} / \mathrm{kg}$

Group III: $\quad$ Hyperglycaemic rats received MSFCE $100 \mathrm{mg} / \mathrm{kg}$

Group IV: $\quad$ Hyperglycaemic rats received MSFCE $200 \mathrm{mg} / \mathrm{kg}$

Group V: $\quad$ Hyperglycaemic rats received MSFCE $400 \mathrm{mg} / \mathrm{kg}$

Group VI: $\quad$ Hyperglycaemic rats received Metformin $100 \mathrm{mg} / \mathrm{kg}$

International Journal of Medicinal Plants and Natural Products (IJMPNP) 
The Antihyperglycaemic Effect of the Methanol Stem-Bark Extract of Ficus capensis Thunb (Moraceae) and its Fractions on Alloxan-Induced Hyperglycaemia in Wistar Rats

The same procedure was repeated for ethyl acetate fraction (EAF), n-butanol (NBF), and residual aqueous (RAF) fractions of methanol stem bark extract of Ficus capensis at doses of 100, 200, and $400 \mathrm{mg} / \mathrm{kg} b w$ p.o respectively.

\subsection{Statistical analysis}

All data were expressed as the mean \pm SEM. Statistical analysis was carried out using the repeated measures ANOVA followed by benforreni and post hoc test for multiple comparisons and the difference considered significant when $(p \leq 0.05)$.

\subsection{Results}

\section{Crude Methanol Stem Bark Extract of Ficus capensis}

The maceration of $500 \mathrm{~g}$ stem bark of Ficus capensis resulted in a dark brown residue which was referred to as crude methanol stem bark extract weighing $85 \mathrm{~g}$ which is equivalent to $17 \%$ w $/{ }_{\text {w }}$ yield.

\section{Fractionation of Crude Methanol Stem Bark Extract of Ficus capensis (MSFCE)}

The fractionation of crude methanol stem bark extract of Ficus capensis yielded five (5) fractions (nHexane, Chloroform, Ethyl acetate, n-Butanol and Residual aqueous). The n-Butanol fraction had the highest yield $61.75(\% \mathrm{w} / \mathrm{w})$ while the yield of $\mathrm{n}$-Hexane fraction was negligible

\section{Phytochemical Constituents of Methanol Stem Bark Extract of Ficus Capensis} AND ITS FRACTIONS

The Phytochemical Constituents of methanolic stem bark extract of Ficus capensis and its Fractions; Ethyl acetate soluble fraction (EAF), n-Butanol soluble fraction (NBF) and Residual aqueous fraction (RBF) revealed the presence of carbohydrate, cardiac glycosides, saponins, steroids, triterpenes, tannins, flavonoids, and alkaloids. Anthraquinone was found to be absent in all the fractions including the methanol stem bark extract of Ficus capensis

\subsection{Effect of acute administration of MSFCE and its Fractions on general behaviour and mortality}

The oral administration of MSFCE and its Fractions produced no visible signs of toxicity and mortality throughout the study period. The $\mathrm{LD}_{50}$ was thus found to be greater than $5000 \mathrm{mg} / \mathrm{kg}$

\subsection{Effect of Methanol Stem Bark Extract of Ficus capensis on Blood Glucose of Alloxan Induced Hyperglycaemia in Wistar Rats}

Methanol Stem Bark Extract of Ficus capensis (MSFCE) at doses of 200 and $400 \mathrm{mg} / \mathrm{kg}$ significantly $(p<0.05)$ decrease blood glucose levels $2 \mathrm{~h}$ after administration. Extract also at a dose of $400 \mathrm{mg} / \mathrm{kg}$ and at 24 hour produced significant $(p<0.05)$ decrease in blood glucose levels when compared with the hyperglycaemic control.

On comparison overtime, the extract at the doses tested did not produce significant $(p>0.05)$ decrease blood glucose level throughout the period of the study as compared to zero hour. Metformin significantly $(p<0.05$ and $p<0.01)$ decreased blood glucose levels from the 0 hour and when compared with the diabetic control at 2, 8 and $24 \mathrm{~h}$ (Table 1).

Table1. Effect of Methanol Stem-Bark Extract of Ficus capensis on Blood Glucose Levels of Alloxan-Induced Hyperglycaemia in Wistar Rats

\begin{tabular}{|l|l|l|l|l|l|c|}
\hline \multirow{2}{*}{ Treatment } & \multirow{2}{*}{ Dose mg/kg } & \multicolumn{5}{|c|}{ Mean Blood Glucose Level (mg/dL) } \\
\cline { 3 - 7 } & & $0 \mathrm{~h}$ & $2 \mathrm{~h}$ & $4 \mathrm{~h}$ & $8 \mathrm{~h}$ & $24 \mathrm{~h}$ \\
\hline & & & & & & \\
\hline D/W & $1 \mathrm{ml} / \mathrm{kg}$ & $74.6 \pm 5.0$ & $82.3 \pm 5.6$ & $81.2 \pm 5.1$ & $82.8 \pm 4.3$ & $102.4 \pm 5.6$ \\
ALX & 150 & $370.1 \pm 14.8$ & $324.0 \pm 5.7$ & $314.2 \pm 9.5$ & $317.5 \pm 11.6$ & $300.3 \pm 17.6$ \\
MSFCE & 100 & $296.4 \pm 12.5$ & $315.3 \pm 10.5$ & $297.1 \pm 19.9$ & $289.2 \pm 19.1$ & $279.6 \pm 25.7$ \\
MSFCE & 200 & $298.3 \pm 12.9$ & $279.4 \pm 19.2^{*}$ & $390.5 \pm 8.5$ & $320.3 \pm 54.8$ & $347.2 \pm 53.8$ \\
\hline
\end{tabular}


The Antihyperglycaemic Effect of the Methanol Stem-Bark Extract of Ficus capensis Thunb (Moraceae) and its Fractions on Alloxan-Induced Hyperglycaemia in Wistar Rats

\begin{tabular}{|l|l|l|l|l|l|l|}
\hline MSFCE & 400 & $326.7 \pm 11.5$ & $292.2 \pm 18.8^{*}$ & $304.3 \pm 26.5$ & $321.0 \pm 19.9$ & $290.5 \pm 17.6^{*}$ \\
MTF & 100 & $308.4 \pm 4.8$ & $253.5 \pm 10.7^{* \mathrm{a}}$ & $292.0 \pm 9.9^{\mathrm{a}}$ & $257.3 \pm 15.8^{* * \mathrm{~b}}$ & $258.9 \pm 11.2^{* * \mathrm{~b}}$ \\
\hline
\end{tabular}

Data were presented as Mean $\pm \mathrm{SEM}$; superscripts $*$, **, and ${ }^{\mathrm{a}, \mathrm{b}}$ represents the level of significance at $p<0.05$ and $p<0.01$ when compared to diabetic control and day zero respectively. Repeated Measures ANOVA followed by Bonferroni post hoc test, $n=6$. D/W=Distilled water, ALX=Alloxan, MSFCE= Methanol Stem Bark Extract of Ficus capensis and MTF= Met

\subsection{Effect of Ethyl Acetate Fraction of Ficus capensis on Blood Glucose of Alloxan Induced Hyperglycaemia in Wistar Rats}

Single administration of ethyl acetate fraction of methanol stem-bark extract of Ficus capensis (EAF) at a doses of $(100,200$ and $400 \mathrm{mg} / \mathrm{kg} b w)$ produced significant $(p<0.05)$ decrease in blood glucose levels of rats at different time intervals $(4,8$, and 16 hour respectively) compared with diabetic control. Metformin at a dose of $100 \mathrm{mg} / \mathrm{kg}$ produced significant $(p<0.001)$ decrease in blood glucose level when compared with the diabetic control. The greatest change of blood glucose level $(38.8 \%)$ was seen with EAF at 100 $\mathrm{mg} / \mathrm{kg} b w$ then followed by EAF at doses of $200,400 \mathrm{mg} / \mathrm{kg} b w(29 \%)$ and $(23.7 \%)$ respectively in decreasing manner while metformin produced glycaemic change of (27.8\%) at first 4 hour post administration. EAF at doses tested $(100,200$ and $400 \mathrm{mg} / \mathrm{kg})$ significantly $(p<0.05)$ decreased blood glucose levels after the $4^{\text {th }}, 8^{\text {th }}$ and $16^{\text {th }}$ hour after administration as compared to 0 hour (Table 2 )

Table2. Effect of Ethyl Acetate Fraction of Ficus capensis on Blood Glucose Levels of Alloxan Induced Hyperglycaemia in Rats

\begin{tabular}{|l|l|l|l|l|l|l|l|}
\hline \multicolumn{9}{|c|}{ Mean Blood Glucose Level $(\mathrm{mg} / \mathrm{dL})$} \\
\hline Treatment & $\mathrm{mg} / \mathrm{kg}$ & $0 \mathrm{~h}$ & $2 \mathrm{~h}$ & $4 \mathrm{~h}$ & $8 \mathrm{~h}$ & $16 \mathrm{~h}$ & $24 \mathrm{~h}$ \\
\hline D/W & $1 \mathrm{ml} / \mathrm{kg}$ & $77.0 \pm 3.8$ & $74.0 \pm 2.3$ & $67.2 \pm 3.5$ & $67.8 \pm 3.7$ & $68.4 \pm 1.4$ & $81.2 \pm 1.8$ \\
\hline ALX & 150 & $439.0 \pm 58.7$ & $367.4 \pm 26.2$ & $343.4 \pm 29.2$ & $358.6 \pm 26.9$ & $356.8 .5 \pm 20$ & $432.8 \pm 35.3$ \\
\hline EAF & 100 & $353.6 \pm 62.6$ & $344.6 \pm 56.2$ & $364.4 \pm 47.7$ & $303.4 \pm 43.3$ & $216.6 \pm 46.6^{* a}$ & $328.2 \pm 59.5$ \\
\hline EAF & 200 & $276.0 \pm 25.4$ & $317.8 \pm 11.7$ & $271.6 \pm 35.3$ & $235.8 \pm 28.0^{*}$ & $196.0 \pm 22.7^{* * a}$ & $227.0 \pm 28.5^{\mathrm{a}}$ \\
\hline EAF & 400 & $308.0 \pm 14.4$ & $243.2 \pm 25.7$ & $221.0 \pm 52.4^{* a}$ & $222.6 \pm 58.5^{* a}$ & $235.2 \pm 51.6^{* a}$ & $331.0 \pm 55.3$ \\
\hline MTF & 100 & $228.4 \pm 29.1$ & $179.0 \pm 36.3^{* *}$ & $164.8 \pm 27.5^{* * a}$ & $198.8 \pm 67.2^{* *}$ & $247.2 \pm 28.2$ & $353.7 \pm 32.8$ \\
\hline
\end{tabular}

Data were presented as Mean \pm SEM; superscripts *, **, and ${ }^{\mathrm{a}, \mathrm{b}}$ represents the level of significance at $p<0.05$ and $p<0.01$ when compared to diabetic control and day zero respectively. Repeated Measures ANOVA followed by Bonferroni post hoc test,.n=6. $\mathrm{D} / \mathrm{W}=$ Distilled water, ALX= Alloxan, EAF= Ethyl acetate Fraction, and MTF $=$ Metformin

\subsection{The Effect of n-Butanol Fraction of Ficus capensis on Blood Glucose Levels of Alloxan Induced Hyperglycaemia in Rats}

Single administration of n-butanol fraction of methanol stem-bark extract of Ficus capensis (NBF) at doses of 100 and $200 \mathrm{mg} / \mathrm{kg} b w$ produced significant $(p<0.05)$ decrease in blood glucose levels of rats and at the $2^{\text {nd }}, 4^{\text {th }}, 8^{\text {th }}$ and $16^{\text {th }}$ hour respectively post administration. Unlike the NBF, metformin at a dose 100 $\mathrm{mg} / \mathrm{kg} b w$ produced significant $(p<0.01)$ decrease in the blood glucose levels of rats at the $2^{\text {nd }}, 4^{\text {th }}$, and $8^{\text {th }}$ hour post administration when compared with the diabetic control (Alloxan $150 \mathrm{mg} / \mathrm{kg} b w$ ). The highest glycaemic change of blood glucose level (BGL) of (52.3\%) was observed with NBF $200 \mathrm{mg} / \mathrm{kg} b w$ of the extract after 16 hour after treatment. On comparison overtime, NBF at doses tested $(100,200$ and 400 $\mathrm{mg} / \mathrm{kg})$ significantly $(p<0.05$ and $p<0.01)$ decreased blood glucose levels at the $2^{\text {nd }}, 4^{\text {th }}, 8^{\text {th }}$ and $16^{\text {th }}$ after administration as compared to 0 hour. Metformin significantly $(p<0.05$ and $p<0.01)$ decreased blood glucose levels at the $2^{\text {nd }}$ and $4^{\text {th }}$ hour respectively after administration as compared to 0 hour (Table 3 )

Table3. The Effect of n-Butanol Fraction of Ficus capensis on Blood Glucose Levels of Alloxan Induced Hyperglycaemia in Rats

\begin{tabular}{|c|c|c|c|c|c|c|}
\hline \multirow[b]{2}{*}{$\operatorname{Tre}$} & \multirow[b]{2}{*}{ Dose } & \multicolumn{5}{|c|}{\begin{tabular}{|l} 
Mean Blood Glucose Level (mg/dL) \\
(m)
\end{tabular}} \\
\hline & & $2 \mathrm{~h}$ & $4 \mathrm{~h}$ & $8 \mathrm{~h}$ & $16 \mathrm{~h}$ & $24 \mathrm{~h}$ \\
\hline
\end{tabular}


The Antihyperglycaemic Effect of the Methanol Stem-Bark Extract of Ficus capensis Thunb (Moraceae) and its Fractions on Alloxan-Induced Hyperglycaemia in Wistar Rats

\begin{tabular}{|l|l|l|l|l|l|l|l|}
\hline & $\mathrm{mg} / \mathrm{kg}$ & \multicolumn{6}{|l|}{} \\
\hline D/W & $1 \mathrm{ml} / \mathrm{kg}$ & $77.0 \pm 3.8$ & $77.4 \pm 2.1$ & $73.6 \pm 1.0$ & $67.2 \pm 3.4$ & $71.6 \pm 3.4$ & $63.4 \pm 1.5$ \\
\hline ALX & 150 & $439.0 \pm 58.7$ & $367.8 \pm 26.2$ & $343.4 \pm 29.2$ & $358.6 \pm 26.9$ & $356.6 \pm 20.2$ & $432.8 \pm 35.3$ \\
\hline NBF & 100 & $347.2 \pm 63.7$ & $315.0 \pm 89.5^{*}$ & $267.4 \pm 72.8^{* \mathrm{a}}$ & $264.6 \pm 70.0^{* \mathrm{a}}$ & $273.4 \pm 76.5^{\mathrm{a}}$ & $326.6 \pm 78.9$ \\
\hline NBF & 200 & $375.2 \pm 25.8$ & $309.8 \pm 15.7^{* \mathrm{a}}$ & $275.6 \pm 18.2^{*_{\mathrm{a}}}$ & $235.2 \pm 22.0^{* \mathrm{a}}$ & $209.4 \pm 25.9^{* \mathrm{~b}}$ & $404.2 \pm 36.0$ \\
\hline NBF & 400 & $461.6 \pm 67.4$ & $346.0 \pm 38.5^{\mathrm{a}}$ & $330.4 \pm 37.8^{\mathrm{a}}$ & $321.8 \pm 39.4^{\mathrm{a}}$ & $384.6 \pm 69.8$ & $520.8 \pm 41.2$ \\
\hline MTF & 100 & $228.4 \pm 29.1$ & $179.0 \pm 36.3^{* * \mathrm{a}}$ & $164.8 \pm 27.5^{* \mathrm{*}}$ & $198.8 \pm 67.2^{* *}$ & $247.2 \pm 28.2$ & $353.7 \pm 32.8$ \\
\hline
\end{tabular}

Data are presented as Mean \pm SEM; superscripts $*, * *$ and ${ }^{\mathrm{a}, \mathrm{b}}$ represents the level of significance at $p<0.05$, and $p<0.01$ when compared to diabetic control and day zero respectively. Repeated Measures ANOVA followed by Bonferroni post hoc test, $\mathrm{n}=6 . \mathrm{D} / \mathrm{W}=$ Distilled water, ALX $=$ Alloxan, NBF $=\mathrm{n}-$ Butanol Fraction, and MTF= Metformin

\subsection{The Effect of Residual Aqueous Fraction of Ficus capensis on Blood Glucose Levels of Alloxan Induced Hyperglycaemia in Rats}

Residual aqueous fraction of methanol stem-bark extract of Ficus capensis (RAF) significantly $(p<0.05)$ decreased blood glucose levels of rats at a dose of $100 \mathrm{mg} / \mathrm{kg} \mathrm{bw}$ at the $4^{\text {th }}$ hour post administration only. Also it significantly $(p<0.05)$ decreased blood glucose levels of rats at a dose of $200 \mathrm{mg} / \mathrm{kg} b w$ and at the $2^{\text {nd }}, 8^{\text {th }}$ and $16^{\text {th }}$ hour post administration. Metformin at a dose $100 \mathrm{mg} / \mathrm{kg} b \mathrm{w}$ produced significant $(p<0.01)$ decrease in the blood glucose levels of rats at the $2^{\text {nd }}, 4^{\text {th }}$, and $8^{\text {th }}$ hour post administration when compared with the diabetic control. RAF at doses tested significantly $(p<0.05$ and $p<0.01)$ decreased blood glucose levels of rats and metformin significantly $(p<0.05$ and $p<0.01)$ decreased blood glucose levels at the $2^{\text {nd }}$ and $4^{\text {th }}$ hour after administration as compared to day 0 (Table 4 ).

Table4. Effect of Residual Aqueous Fraction of Ficus capensis on Blood Glucose Levels of Alloxan Induced Hyperglycaemia in Rats

\begin{tabular}{|l|l|l|l|l|l|l|l|}
\hline \multicolumn{2}{|l|}{ Mean Blood Glucose Level (mg/dL) } \\
\hline Treatment & $\begin{array}{l}\text { Dose } \\
\mathrm{mg} / \mathrm{kg}\end{array}$ & $0 \mathrm{~h}$ & $2 \mathrm{~h}$ & $4 \mathrm{~h}$ & $8 \mathrm{~h}$ & $16 \mathrm{~h}$ & $24 \mathrm{~h}$ \\
\hline D/W & $\begin{array}{l}1 \\
\mathrm{ml} / \mathrm{kg}\end{array}$ & $77.0 \pm 3.8$ & $77.4 \pm 2.1$ & $73.6 \pm 1.0$ & $67.2 \pm 3.4$ & $71.6 \pm 3.4$ & $63.4 \pm 1.5$ \\
\hline ALX & 150 & $439.0 \pm 58.7$ & $367.8 \pm 26.2$ & $343.4 \pm 29.2$ & $358.6 \pm 26.9$ & $356.6 \pm 20.2$ & $432.8 \pm 35.3$ \\
\hline RAF & 100 & $316.2 \pm 20.3$ & $309.4 \pm 11.1$ & $254.6 \pm 9.4^{* a}$ & $240.2 \pm 17.4^{* a}$ & $216.4 \pm 11.4^{\mathrm{b}}$ & $360.0 \pm 8.3$ \\
\hline RAF & 200 & $313.0 \pm 17.5$ & $270.8 \pm 5.5^{*}$ & $269.2 \pm 4.0$ & $205.6 \pm 4.0^{* \mathrm{~b}}$ & $205.0 \pm 14.1^{* \mathrm{~b}}$ & $391.6 \pm 14.3$ \\
\hline RAF & 400 & $313.4 \pm 23.5$ & $287.6 \pm 36.3$ & $262.4 \pm 15.7^{*}$ & $227.0 \pm 21.7^{* \mathrm{~b}}$ & $211.8 \pm 11.9^{\mathrm{b}}$ & \\
\hline MTF & 100 & $228.4 \pm 29.1$ & $179.0 \pm 36.3^{* * a}$ & $164.8 \pm 27.5^{* * \mathrm{~b}}$ & $198.8 \pm 67.2^{* *}$ & $247.2 \pm 28.2$ & $353.7 \pm 32.8$ \\
\hline
\end{tabular}

Data were analysed using Repeated Measures ANOVA followed by Bonferroni post hoc test and presented as Mean \pm SEM, superscripts $*, * *$ and ${ }^{\mathrm{a}, \mathrm{b}}$ the level of significance at $p<0.05$ and $p<0.01$ when compared to diabetic control and day zero respectively. $\mathrm{n}=6 . \mathrm{D} / \mathrm{W}=$ Distilled water, $\mathrm{ALX}=$ Alloxan, RAF $=$ Residual Aqueous Fraction, and MTF $=$ Metformin

\section{DisCUSSION}

The oral median lethal dose $\left(\mathrm{LD}_{50}\right)$ of the methanol stem bark extract of Ficus capensis in rats was found to be greater than $5000 \mathrm{mg} / \mathrm{kg}$ body weight which is relatively safe because no death was recorded even at higher dose of $5000 \mathrm{mg} / \mathrm{kg}$. The Organization for Economic Cooperation and Development (OECD), Paris, France (Walum, 1998) recommended chemical labeling and classification of acute systemic toxicity 
based on oral $\mathrm{LD}_{50}$ values as: very toxic, $\leq 5 \mathrm{mg} / \mathrm{kg}$; toxic, $>5 \leq 50 \mathrm{mg} / \mathrm{kg}$; harmful, $>50 \leq 500 \mathrm{mg} / \mathrm{kg}$; and not toxic or harmful, $>500 \leq 2,000 \mathrm{mg} / \mathrm{kg}$. However, the doses selected used in this work were lower than $30 \%$ of the $\mathrm{LD}_{50}$ which have been shown to be relatively safe for ethnopharmacological research (Voungtau, et al., 2004).

In the present study, methanol stem bark extract of Ficus capensis (MSFCE) and its fractions: ethyl acetate fraction (EAF), n-butanol fraction $(\mathrm{NBF})$, and residual aqueous fraction ( $\mathrm{RBF}$ ) significantly decreased the blood glucose levels (BGL). Significant reduction in BGL followed the pattern in group treated with metformin. The significant decrease in blood glucose levels is an indication that the extract and its fractions have antihyperglycaemic activity which could be attributed to the presence phytochemical constituent's steroids, triterpenes, glycosides, alkaloids, flavonoids, phenols, and saponins. This is in agreement with earlier report by (Roy et al., 2006), the presence of secondary metabolites such as saponins, alkaloids and flavonoids in Mangifera indica are responsible for the antihyperglycaemic effect. Studies have also shown that the administration of Gymnema sylvestre extract, saponin fraction or isolated triterpene glycosides is responsible for prolong antidiabetic effect of insulin and extended reduced blood glucose levels (Di Fabio et al., 2013 and Alqantani et al., 2013).

The phytochemical constituents of methanol stem bark extract of Ficus capensis revealed the presence of phenols flavonoids, alkaloids, tannins, saponins, steroids and triterpenes which may be responsible, in part or in combination for the observed pharmacological activities of the plant extract. Researchers have found that they are implicated as having antidiabetic activities (Malviya et al., 2010). Literature has also shown that the biological activities of alkaloids and flavonoids to include hypoglycaemia, hypolipidemia, hypoazotemia, hypotension among other biological effects (Sani et al., 2009). The antidiabetic activities could be obtained from several parts of the plants such as the aerial parts, bark, flower, root, seeds, leaves, bulb, tubers and/or whole plant (Maroo et al., 2002).

Also the possible mechanism by which MSFCE and its fractions bring about its blood glucose lowering action is by potentiating the insulin effect by increasing the pancreatic secretion of insulin from $\beta$ cell. The findings also suggest the extract and its fractions may act by promoting insulin secretion from the remnants of $\beta$ cells and improving insulin sensitivity.

In our study, treatment with MSFCE and its fractions proved effective in managing hyperglycaemia because blood glucose levels was found to have normalized or near normal. As this was only observed in alloxan treated hyperglycaemic rats.

Thus, the results obtained from this study suggest that the crude methanol stem bark of Ficus capensis and its fractions contained bioactive constituents that may have relevant antidiabetic properties used in the management of diabetes mellitus.

\section{CONCLUSION}

The methanol stem bark extract of Ficus capensis and its fraction were found to possess significant antihyperglycaemic activity. This justifies the traditional use of the plant in the management of diabetes mellitus.

\section{REFERENCES}

[1] Alqantani, A., Hamid, K., Kam, A., Wong, K.H., Abdelhak, Z., Razmovski-Naumovski, V., Chan, K., Li, K.M., and Groundwater, P.W (2013). The pentacyclic triterpenoids in herbal medicine and their pharmacological activities in diabetes and diabetic complication. Current Medicinal Chemistry, 20: 908 $-931$

[2] American Diabetic Association (2013). Diagnosis and Classification of Diabetes mellitus. Diabetes care, vol. 36, issue1: $67-74$.

[3] Dhandapani, S., Subramanian, R. V., Ranjagopal, S., Namasivajam, N. (2002). Hypolipidaemic effect of Cuminum cyminum L. on alloxan-induced diabetic rats. Pharmaceutical Research, 46: 3

[4] Di Fabio, G., Romanucci, V., Zarelli, M., Giodano, M., Zarelli, A (2013). C-4 gem- dimethylted oleans of Gymnema sylvestre and their pharmacological activities. Molecules, 18: 14892 - 14919 
The Antihyperglycaemic Effect of the Methanol Stem-Bark Extract of Ficus capensis Thunb (Moraceae) and its Fractions on Alloxan-Induced Hyperglycaemia in Wistar Rats

[5] Drews, G., Kramer, C., Dufer, M., Krippeit-Drews, P. (2000). Contrasting effects of alloxan on islets and single mouse Pancreatic $\beta$-cells. Biochemistry Journal; 352 - 389.

[6] Evans, W. C. (2002). Preliminary phytochemical screening of secondary metabolites in Trease and Evans Pharmacognosy, (Fifteen Edition) Sanders Company Limited pp 191 - 193.

[7] Fowler, M.J (2008). Microvascular and Macrovascular Complications of Diabetes. Diabetes Care, 26(2): 77 82

[8] Gorus, F. K., Malaisse, W. J., Pipeleers, D, G. (1982). Selective uptake of alloxan by pancreatic $\beta$-cells. Biochemistry Journal, 208: $513-515$.

[9] Handa, S.S., Khanuja, S.P.S., Longo, G., Rakesh, D.D., (2008). Extraction Technologies for Medicinal and Aromatic Plants ( $1^{\text {st }}$ Edition), no. 66 Italy: United Nations Industrial =Developmental Organization and International Centre for Science and High Technology.

[10] Igoli, J.O., Ogaji, O.G., Tor-Aryiin, A., and Igoli, N.P. (2005). Traditional Medicinal Amongst the Igede people of Nigeria. Part II. African Journal of Traditional and Complementary Alternative Medicine, 2(2):134 - 152.

[11] International Diabetes Federation (IDF), (2015). The diabetes atlas $7^{\text {th }}$ edition update. =www.idf.org/diabetesatlas. Acessed 10/01/ 2016

[12] Lorenzati, B., Zucco, C., Miglietta, S., Lamberti, F., and Bruno, G. (2010) Oral $\quad$ hypoglycemic drugs: pathophysiological basis of their mechanism of action. Pharmaceuticals, 3: $\quad 3005-3020$.

[13] Lorke, D. (1983). A New Approach to Practical Acute Toxicity Testing, Archives of Toxicology 54: 275-287

[14] Malviya, N., Jain, S., Malviya, S (2010). Antidiabetic potential of medicinal plants. Acta Poland Pharmaceuticals; 67(2): 113-118.

[15] Maroo, J., Vasu, V.T., Aalinkeel, R., Gupta, S (2002). Glucose lowering effect of aqueous extract of Enicostemma littorale Blume in diabetes: a possible mechanism of action. Journal of Ethnopharmacology; 81(3): $317-3$

[16] Roy, K. C., Jagadish, V. K., and Mohammed, A. (2006). Hepatoprotective activity of P. guajava leaf extract. Indian Journal of Experimental Biology, 44: 305 - 311.

[17] Sani, D., Sanni, S., and Ngulde, S.I. (2009). Phytochemical and antimicrobial screening of the stem aqueous extract of Anisopus mannii; 3(3):112-115.http://www. Academicjournals.org/JMPR

[18] Soladoye, M.O., Chukwuma, E.C., and Owa, F.P. (2012): An avalanche of plant species for the Traditional Cure of Diabetes Mellitus in South-Western Nigeria. Journal of Natural Production and Plant Resources; 2(1): 60-70.

[19] Suleiman, I.A., Fadeke, O.F., and Okubanjo, O.O. (2006). Pharmacoeconomic Evaluation of Anti-Diabetic Therapy in A Nigerian Tertiary Institution. Annals of African Medicine, 5(3):132 - 137.

[20] Szukudelski, T. (2001). The mechanism of alloxan and streptozotocin in $\beta$-cells of the pancreas. Physiology Research, 50: 536 - 546.

[21] Voungtau, H.O., Abbah, J., Ngazal, I.E., Kunle, O.F., Chindo, B.A., Otsapa, P.B. and Gammaniel, K.S. (2004). Antinociceptive and anti-inflammatory activities of the methanolic extract of Pinanari polyandra stem bark in rats and mice. Journal of Ethnopharmacology, 90: 115-121

[22] Walum, E. (1998). Acute oral toxicity. Environmental Health Perspectives 106: 497 - 503

[23] Wild, S., Roglic, G., Green, A., Sicree, R., and King, H. (2004). Global prevalence of Diabetes: Estimates for the year 2000 and projection for 2030. Diabetes care; 27: $1047-1053$.

[24] Wolf, A. M., Conaway, M. R., Crowther, J. Q., Hazen, K. Y., Nadler, J., Oneida, B. (2004). Translating life style intervention to practice in obese patients with type 2 Diabetes: Improving control with activity and nutrition (ICAN) study. Diabetes Care; 27: 1570 - 1576

APPENDIX

Appendix I: Crude Methanol Stem Bark Extract of Ficus capensis

The maceration of $500 \mathrm{~g}$ stem bark of Ficus capensis resulted in a dark brown residue which was referred to as crude methanol stem bark extract weighing $85 \mathrm{~g}$ which is equivalent to $17 \% \mathrm{w} / \mathrm{w}$ yield.

Appendix II: Fractionation of Crude Methanol Stem Bark Extract of Ficus capensis (MSFCE)

The fractionation of crude methanol stem bark extract of Ficus capensis yielded five (5) fractions (nHexane, Chloroform, Ethyl acetate, n-Butanol and Residual aqueous). The n-Butanol fraction had the highest yield $61.75(\% \mathrm{w} / \mathrm{w})$ while the yield of $\mathrm{n}$-Hexane fraction was negligible 
The Antihyperglycaemic Effect of the Methanol Stem-Bark Extract of Ficus capensis Thunb (Moraceae) and its Fractions on Alloxan-Induced Hyperglycaemia in Wistar Rats

Appendix III: Oral $L D_{50}$ determination in rats for Methanol Stem Bark Extract of Ficus capensis using Lorke method 1983

Phase I

\begin{tabular}{|lccc|}
\hline Group & Treatment & Dose $\mathrm{mg} / \mathrm{kg}$ & Mortality $\%$ \\
\hline I & MSFCE & 10 & $0 / 3$ (none died) \\
II & MSFCE & 100 & $0 / 3$ (none died) \\
III & MSFCE & 1000 & $0 / 3$ (none died) \\
\hline
\end{tabular}

Phase II

\begin{tabular}{lccc}
\hline Group & Treatment & Dose $\mathrm{mg} / \mathrm{kg}$ & Mortality \% \\
\hline I & MSFCE & 1600 & $0 / 1$ (no death) \\
II & MSFCE & 2900 & $0 / 1$ (no death) \\
III & MSFCE & 5000 & $0 / 1$ (no death) \\
\hline
\end{tabular}

$\mathrm{LD}_{50}=\sqrt{ }$ Geometric mean of lethal dose $(\mathrm{X})$ and highest non lethal dose $(\mathrm{Y})$

Therefore, $\mathrm{LD}_{50}$ in both mice and rats was found to be greater than $5000 \mathrm{mg} / \mathrm{kg}$.

The oral $\mathrm{LD}_{50}$ of Ethyl acetate, $\mathrm{n}$ - Butanol and Residual Aqueous Fractions in both mice and rats was greater 5000 $\mathrm{mg} / \mathrm{kg}$

AppendixIV: Effect of Methanol Stem-Bark Extract of Ficus capensis on Blood Glucose Levels of Alloxan-Induced Hyperglycaemia in Wistar Rats

\begin{tabular}{|c|c|c|c|c|c|c|}
\hline \multirow{2}{*}{ Treatment } & \multirow{2}{*}{$\begin{array}{l}\text { Dose } \\
\mathrm{mg} / \mathrm{kg}\end{array}$} & \multicolumn{5}{|c|}{ Mean Blood Glucose Level (mg/dL) } \\
\hline & & $\mathrm{Oh}$ & $2 \mathrm{~h}$ & $4 \mathrm{~h}$ & $8 \mathrm{~h}$ & $24 \mathrm{~h}$ \\
\hline $\mathrm{D} / \mathrm{W}$ & $1 \mathrm{ml} / \mathrm{kg}$ & $74.6 \pm 5.0$ & $82.3 \pm 5.6$ & $81.2 \pm 5.1$ & $82.8 \pm 4.3$ & $102.4 \pm 5.6$ \\
\hline ALX & 150 & $370.1 \pm$ & $324.0 \pm 5.7$ & $314.2 \pm$ & $317.5 \pm 11.6$ & $300.3 \pm 17.6$ \\
\hline MSFCE & 100 & 14.8 & $315.3 \pm 10.5$ & 9.5 & $289.2 \pm 19.1$ & $279.6 \pm 25.7$ \\
\hline MSFCE & 200 & $296.4 \pm$ & $279.4 \pm$ & $297.1 \pm$ & $320.3 \pm 54.8$ & $347.2 \pm 53.8$ \\
\hline MSFCE & 400 & 12.5 & $19.2^{*}$ & 19.9 & $321.0 \pm 19.9$ & $290.5 \pm$ \\
\hline \multirow[t]{6}{*}{ MTF } & 100 & $298.3 \pm$ & $292.2 \pm$ & $390.5 \pm$ & $257.3 \pm 15.8^{* * b}$ & $17.6^{*}$ \\
\hline & & 12.9 & $18.8^{*}$ & 8.5 & & $258.9 \pm$ \\
\hline & & $326.7 \pm$ & $253.5 \pm$ & $304.3 \pm$ & & $11.2^{* * b}$ \\
\hline & & 11.5 & $10.7^{* a}$ & 26.5 & & \\
\hline & & $308.4 \pm$ & & $292.0 \pm$ & & \\
\hline & & 4.8 & & $9.9^{\mathrm{a}}$ & & \\
\hline
\end{tabular}

Data were presented as Mean $\pm \mathrm{SEM}$; superscripts $*$, **, and ${ }^{\mathrm{a}, \mathrm{b}}$ represents the level of significance at $p<0.05$ and $p<0.01$ when compared to diabetic control and day zero respectively. Repeated Measures ANOVA followed by Bonferroni post hoc test, $n=6$. D/W=Distilled water, ALX=Alloxan, MSFCE= Methanol Stem Bark Extract of Ficus capensis and MTF= Met 
The Antihyperglycaemic Effect of the Methanol Stem-Bark Extract of Ficus capensis Thunb (Moraceae) and its Fractions on Alloxan-Induced Hyperglycaemia in Wistar Rats

AppendixV. Effect of Ethyl Acetate Fraction of Ficus capensis on Blood Glucose Levels Induced Hyperglycaemia in Rats

of $\quad$ Alloxan

\begin{tabular}{|c|c|c|c|c|c|c|c|}
\hline \multirow[b]{2}{*}{ Treatment } & \multirow[b]{2}{*}{$\mathrm{mg} / \mathrm{kg}$} & \multicolumn{6}{|c|}{ Mean Blood Glucose Level (mg/dL) } \\
\hline & & $0 \mathrm{~h}$ & $2 \mathrm{~h}$ & $4 \mathrm{~h}$ & $8 \mathrm{~h}$ & $16 \mathrm{~h}$ & $24 \mathrm{~h}$ \\
\hline $\mathrm{D} / \mathrm{W}$ & $1 \mathrm{ml} / \mathrm{kg}$ & $77.0 \pm 3.8$ & $74.0 \pm 2.3$ & $67.2 \pm 3.5$ & $67.8 \pm 3.7$ & $68.4 \pm 1.4$ & $81.2 \pm 1.8$ \\
\hline ALX & 150 & $439.0 \pm 58.7$ & $367.4 \pm 26.2$ & $343.4 \pm 29.2$ & $358.6 \pm 26.9$ & $356.8 .5 \pm 20$ & $432.8 \pm 35.3$ \\
\hline EAF & 100 & $353.6 \pm 62.6$ & $344.6 \pm 56.2$ & $364.4 \pm 47.7$ & $303.4 \pm 43.3$ & $216.6 \pm 46.6^{* a}$ & $328.2 \pm 59.5$ \\
\hline EAF & 200 & $276.0 \pm 25.4$ & $317.8 \pm 11.7$ & $271.6 \pm 35.3$ & $235.8 \pm 28.0^{*}$ & $196.0 \pm 22.7^{* *_{a}}$ & $227.0 \pm 28.5^{\mathrm{a}}$ \\
\hline EAF & 400 & $308.0 \pm 14.4$ & $243.2 \pm 25.7$ & $221.0 \pm 52.4^{* a}$ & $222.6 \pm 58.5^{*_{a}}$ & $235.2 \pm 51.6^{* a}$ & $331.0 \pm 55.3$ \\
\hline MTF & 100 & $228.4 \pm 29.1$ & $179.0 \pm 36.3^{* 8}$ & $164.8 \pm 27.5^{* *_{a}}$ & $198.8 \pm 67.2^{* *}$ & $247.2 \pm 28.2$ & $353.7 \pm 32.8$ \\
\hline
\end{tabular}

Data were presented as Mean \pm SEM; superscripts $*$, **, and ${ }^{\mathrm{a}, \mathrm{b}}$ represents the level of significance at $p<0.05$ and $p<0.01$ when compared to diabetic control and day zero respectively. Repeated Measures ANOVA followed by Bonferroni post hoc test,.n=6. D/W= Distilled water, ALX= Alloxan, EAF= Ethyl acetate Fraction, and MTF $=$ Metformin

AppendixVI: The Effect of n-Butanol Fraction of Ficus capensis on Blood Glucose Levels of Alloxan Induced Hyperglycaemia in Rats

\begin{tabular}{|c|c|c|c|c|c|c|c|}
\hline \multirow{3}{*}{ Treatment } & \multirow{3}{*}{$\begin{array}{l}\text { Dose } \\
\mathrm{mg} / \mathrm{kg}\end{array}$} & \multicolumn{5}{|c|}{ Mean Blood Glucose Level (mg/dI) } & \\
\hline & & $0 \mathrm{~h}$ & $2 \mathrm{~h}$ & $4 \mathrm{~h}$ & $8 \mathrm{~h}$ & $16 \mathrm{~h}$ & \\
\hline & & $24 \mathrm{~h}$ & & & & & \\
\hline $\mathrm{D} / \mathrm{W}$ & $1 \mathrm{ml} / \mathrm{kg}$ & $77.0 \pm 3.8$ & $77.4 \pm 2.1$ & $73.6 \pm 1.0$ & $67.2 \pm 3.4$ & $71.6 \pm 3.4$ & $63.4 \pm 1.5$ \\
\hline $\mathrm{ALX}$ & 150 & $439.0 \pm 58.7$ & $367.8 \pm 26.2$ & $343.4 \pm 29.2$ & $358.6 \pm 26.9$ & $356.6 \pm 20.2$ & $432.8 \pm 35.3$ \\
\hline NBF & 100 & $347.2 \pm 63.7$ & $315.0 \pm 89.5^{*}$ & $267.4 \pm 72.8^{* a}$ & $264.6 \pm 70.0^{* a}$ & $273.4 \pm 76.5^{\mathrm{a}}$ & $326.6 \pm 78.9$ \\
\hline NBF & 200 & $375.2 \pm 25.8$ & $309.8 \pm 15.7^{\star a}$ & $275.6 \pm 18.2^{* \mathrm{a}}$ & $235.2 \pm 22.0 * \mathrm{a}$ & $209.4 \pm 25.9^{* b}$ & $404.2 \pm 36.0$ \\
\hline NBF & 400 & $461.6 \pm 67.4$ & $346.0 \pm 38.5^{\mathrm{a}}$ & $330.4 \pm 37.8^{\mathrm{a}}$ & $321.8 \pm 39.4^{\mathrm{a}}$ & $384.6 \pm 69.8$ & $520.8 \pm 41.2$ \\
\hline MTF & 100 & $228.4 \pm 29.1$ & $179.0 \pm 36.3^{* 4 \mathrm{a}}$ & $164.8 \pm 27.5^{* * b}$ & $198.8 \pm 67.2^{* *}$ & $247.2 \pm 28.2$ & $353.7 \pm 32.8$ \\
\hline
\end{tabular}

Data are presented as Mean \pm SEM; superscripts $*, * *$ and ${ }^{\mathrm{a}, \mathrm{b}}$ represents the level of significance at $p<0.05$, and $p<0.01$ when compared to diabetic control and day zero respectively. Repeated Measures ANOVA followed by Bonferroni post hoc test, $\mathrm{n}=6 . \mathrm{D} / \mathrm{W}=$ Distilled water, ALX $=$ Alloxan, NBF= $\mathrm{n}$ Butanol Fraction, and MTF= Metformin 
The Antihyperglycaemic Effect of the Methanol Stem-Bark Extract of Ficus capensis Thunb (Moraceae) and its Fractions on Alloxan-Induced Hyperglycaemia in Wistar Rats

AppendixVII. Effect of Residual Aqueous Fraction of Ficus capensis on Blood Glucose Levels of Alloxan Induced Hyperglycaemia in Rats

\begin{tabular}{|c|c|c|c|c|c|c|c|}
\hline \multirow[b]{2}{*}{ Treatment } & \multirow[b]{2}{*}{ Dose $\mathrm{mg} / \mathrm{kg}$} & \multicolumn{5}{|c|}{ Mean Blood Glucose Level (mg/dL) } & \multirow[b]{2}{*}{$24 \mathrm{~h}$} \\
\hline & & $\mathrm{Oh}$ & $2 \mathrm{~h}$ & $4 \mathrm{~h}$ & $8 \mathrm{~h}$ & $16 \mathrm{~h}$ & \\
\hline $\mathrm{D} / \mathrm{w}$ & $1 \mathrm{ml} / \mathrm{kg}$ & $77.0 \pm 3.8$ & $77.4 \pm 2.1$ & $73.6 \pm 1.0$ & $67.2 \pm 3.4$ & $71.6 \pm 3.4$ & $63.4 \pm 1.5$ \\
\hline $\mathrm{ALX}$ & 150 & $439.0 \pm 58.7$ & $367.8 \pm 26.2$ & $343.4 \pm 29.2$ & $358.6 \pm 26.9$ & $356.6 \pm 20.2$ & $432.8 \pm 35.3$ \\
\hline RAF & 100 & $316.2 \pm 20.3$ & $309.4 \pm 11.1$ & $254.6 \pm 9.4^{-3}=$ & $240.2 \pm 17.4^{*=}$ & $216.4 \pm 11.4^{2}$ & $360.0 \pm 8.3$ \\
\hline RAF & 200 & $313.0 \pm 17.5$ & $270.8 \pm 5.5^{*}$ & $269.2 \pm 4.0$ & $205.6 \pm 4.0^{\circ}$ & $205.0 \pm 14.1^{\circ}$ & $391.6 \pm 14.3$ \\
\hline RAF & 400 & $313.4 \pm 23.5$ & $287.6 \pm 36.3$ & $262.4 \pm 15.7^{\circ}$ & $227.0 \pm 21.7^{\circ}$ & $211.8 \pm 11.9^{8}$ & $375.2 \pm 32.0$ \\
\hline MTF & 100 & $228.4 \pm 29.1$ & $179.0 \pm 36.3^{-m}$ & $164.8 \pm 27.5^{\circ}$ & $198.8 \pm 67.2^{*-}$ & $247.2 \pm 28.2$ & $353.7 \pm 32.8$ \\
\hline
\end{tabular}

Data were analysed using Repeated Measures ANOVA followed by Bonferroni post hoc test and presented as Mean \pm SEM, superscripts $* * *$ and ${ }^{\mathrm{a}, \mathrm{b}}$ the level of significance at $p<0.05$ and $p<0.01$ when compared to diabetic control and day zero respectively. $\mathrm{n}=6 . \mathrm{D} / \mathrm{W}=$ Distilled water, $\mathrm{ALX}=$ Alloxan, RAF = Residual Aqueous Fraction, and MTF = Metform

Citation: Mohammed Bashir, et.al., (2020). "The Antihyperglycaemic Effect of the Methanol Stem-Bark Extract of Ficus capensis Thunb (Moraceae) and its Fractions on Alloxan-Induced Hyperglycaemia in Wistar Rats". International Journal of Medicinal Plants and Natural Products (IJMPNP), 6(3), pp.13-23. http://dx.doi.org/ 10.20431 /2454-7999.0603002

Copyright: (0) 2020 Authors. This is an open-access article distributed under the terms of the Creative Commons Attribution License, which permits unrestricted use, distribution, and reproduction in any medium, provided the original author and source are credited. 